\title{
Quantification of volatile organic compounds in smoke from prescribed burning and comparison with occupational exposure limits
}

\author{
E. Romagnoli, T. Barboni, P.-A. Santoni, and N. Chiaramonti \\ SPE UMR 6134 CNRS, University of Corsica, Campus Grimaldi, BP 52, 20250 Corte, France \\ Correspondence to: T. Barboni (barboni@univ-corse.fr)
}

Received: 30 September 2013 - Published in Nat. Hazards Earth Syst. Sci. Discuss.: 15 November 2013

Revised: 16 March 2014 - Accepted: 25 March 2014 - Published: 6 May 2014

\begin{abstract}
Prescribed burning represents a serious threat to personnel fighting fires due to smoke inhalation. The aim of this study was to investigate exposure by foresters to smoke from prescribed burning, focusing on exposure to volatile organic compounds (VOCs). The methodology for smoke sampling was first evaluated. Potentially dangerous compounds were identified among the VOCs emitted by smoke fires at four prescribed burning plots located around Corsica. The measured mass concentrations for several toxic VOCs were generally higher than those measured in previous studies due to the experimental framework (short sampling distance between the foresters and the flame, low combustion, wet vegetation). In particular, benzene, phenol and furfural exceeded the legal short-term exposure limits published in Europe and/or the United States. Other VOCs such as toluene, ethybenzene or styrene remained below the exposure limits. In conclusion, clear and necessary recommendations were made for protection of personnel involved in fighting fires.
\end{abstract}

\section{Introduction}

The large quantities of smoke produced during forest fires can remain in the atmosphere for many days (Dokas et al., 2007). Smoke is composed primarily of carbon dioxide, water vapor, carbon monoxide, particulate matter, hydrocarbons and other organic chemicals, nitrogen oxides, trace minerals, and several thousand other compounds (Barboni and Chiaramonti, 2010; Barboni et al., 2006, 2010b; Dost, 1991; Miranda, 2004; Statheropoulos and Karma, 2007; Urbanski et al., 2009; Ward, 1999). Pollutants that have been insufficiently characterized in smoke include volatile organic compounds (VOCs) and semi-volatile organic compounds (SVOCs). VOCs include hydrocarbons (Miranda, 2004; Statheropoulos and Karma, 2007; Shauer et al., 2001; Ward, 1998) and aromatic hydrocarbons (Barboni et al., 2010; Reisen, 2006; Reisen and Brown, 2009). In addition, VOCs include oxygenated compounds such as alcohols (Barboni et al., 2010; Statheropoulos and Karma, 2007; Shauer et al., 2001), aldehydes (Barboni et al., 2010; Statheropoulos and Karma, 2007; Reinhardt and Ottmar, 2004; Shauer et al., 2001), ketones (Barboni et al., 2010; Statheropoulos and Karma, 2007), furans, carboxylic acids, esters (Barboni et al., 2010; Muraleedharan et al., 2000; Statheropoulos and Karma, 2007), and isoprenoid compounds (Barboni et al., 2011; Evtyugina et al., 2013). Although there is a lack of data on the smoke, there have been many recent studies focused on particles emissions from wildfire due to their potential effect on health (Alves et al., 2001; Vicente et al., 2012, 2013). Smoke chemical characterization was conducted worldwide in tropical savannahs and forests, grassland or boreal temperate zones (Andreae and Merlet, 2001; Friedli et al., 2001; Gouw et al., 2006; Shirai et al., 2003; Sinha et al., 2003, 2004; Yokelson et al., 2007, 2008). Only a few studies relate to Mediterranean vegetation fire (Barboni et al., 2010b; Statheropoulos and Karma, 2007).

Among the VOCs identified in smoke from forest fires, only a few of these compounds have known toxicity and associated short-term exposure limits (STELs) and timeweighted average (TWA) values. VOCs such as formaldehyde, acrolein, benzene, toluene, xylenes, and phenol have been identified by several authors, based on available data 
from prescribed burns (Barboni and Chiaramonti, 2010; De Vos et al., 2009; Reisen and Brown, 2009; Statheropoulos and Karma, 2007), wildfires (Evtyugina et al., 2013), smoke chambers (De Vos et al., 2009; Yokelson et al., 2008), and chimney combustion experiments (Ciccioli et al., 2001; Evtyugina et al., 2014). Formaldehyde and acrolein have been identified as the main toxic VOCs emitted by bushfires (Reinhardt et al., 2001; Reinhardt and Ottmar, 2004); other studies have also identified these compounds, as well as acetaldehyde, benzene, toluene, xylene, and phenol (Barboni et al., 2010; De Vos et al., 2009; Reisen, 2006; Statheropoulos and Karma, 2007). Evtyugina (2013) reported that benzene and toluene are major components of the identified VOCs and that 2-furaldehyde and hexanal were the major SVOCs. These compounds were found at concentrations $<1 \mathrm{ppm}$, differing from levels identified during a forest fire incident in Greece and higher than those noted in other studies (De Vos et al., 2009; Reisen, 2006; Reisen and Brown, 2009; Statheropoulos and Karma, 2007). Therefore, it is important to assess exposure levels for Mediterranean conditions on a local basis. It is possible to measure total VOCs using sampling devices with appropriate detectors. Miranda et al. (2010) measured total VOCs and demonstrated a maximum VOC concentration of $88 \mathrm{ppmv}$ in fire experiments. However, national and international regulatory standards such as the Threshold Limit Value (TLV)-TWA, (TLV)-STEL, or peak limits are established individually for specific compounds, but not collectively for total VOCs (Miranda et al., 2010).

Compounds emitted by smoke may present an important public health issue for communities directly affected and particularly for personnel involved in firefighting operations (Barboni et al., 2010; Miranda et al., 1994, 2010; Reinhardt et al., 2001, 2004; Ward et al., 1973). To assess the combined effects of compounds in smoke on the respiratory system, Reisen and Brown (2009) and Slaughter et al. (2004) have used an index called $E_{m}$, which provides a respiratory irritant exposure index. Effects on firefighters may be acute, subchronic, or chronic and are typically associated with acute decreases in respiratory function with increasing exposure (Barboni et al., 2010; Miranda et al., 1994, 2010; Reinhardt et al., 2001; Slaughter et al., 2004; Ward et al., 1973). Several studies have concluded that exposure to smoke from prescribed burning is associated with significant degeneration in lung function (Materna et al., 1992; Malilay, 1999; Mustajbegovic et al., 2001; Liu et al., 1992; Reinhardt et al., 2000; Rothman et al., 1991), while others found less significant degeneration (Betchley et al., 1997; Slaughter et al., 2004).

The objective of this study is to identify VOCs emitted during a vegetation fire and to determine the most toxic VOCs present in the smoke to protect foresters during prescribed burns. A previous work was conducted to develop the methodology for qualitative analysis of VOCs in smoke (Barboni et al., 2010b). This study allowed us to identify 79 VOCs (> C3) without assessing the toxicity of these pollu-

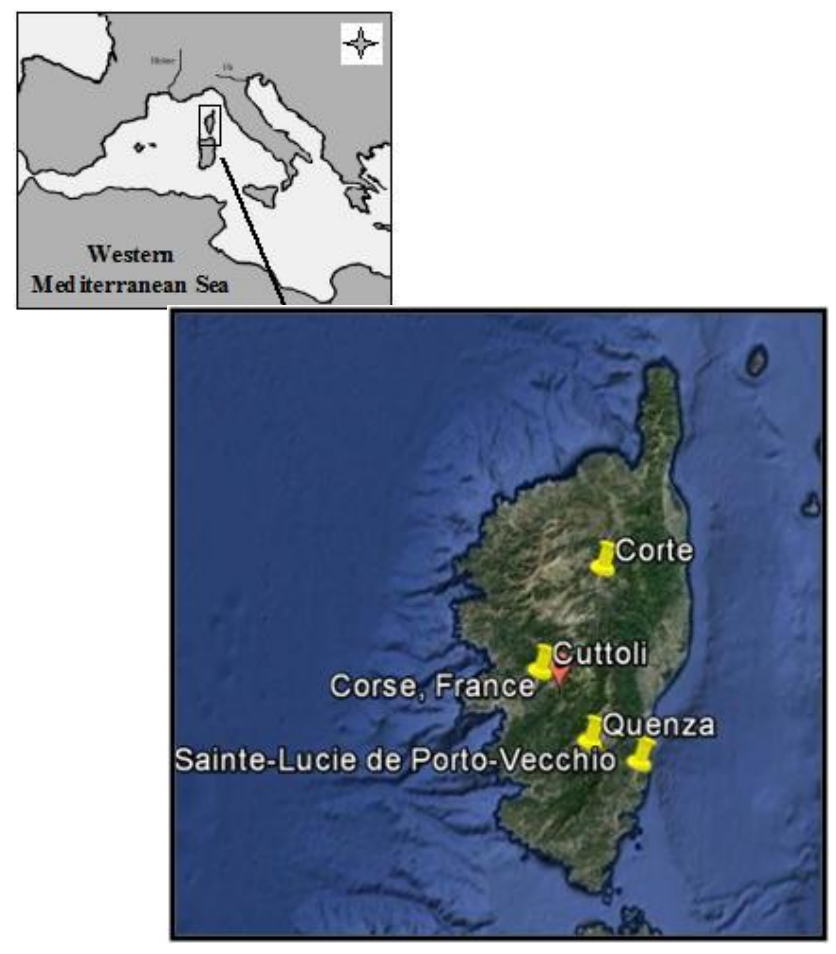

Fig. 1. Location of the study plots on Corsica (French island).

Table 1. Main characteristics of the experimental plots.

\begin{tabular}{|c|c|c|c|c|}
\hline & Site 1 & Site 2 & Site 3 & Site 4 \\
\hline Elevation (m) & 0 & 650 & 400 & 800 \\
\hline Slope $(\%)$ & $0-2$ & $0-10$ & 0 & $0-20$ \\
\hline Vegetation height $(\mathrm{cm})$ & $80-250$ & $80-150$ & $1-10$ & $10-20$ \\
\hline Fuel load $\left(\mathrm{g} \mathrm{m}^{-2}\right)$ & 1160 & 1200 & 1370 & 1450 \\
\hline Vegetation cover $(\%)$ & $50-60$ & $50-60$ & $60-70$ & $70-80$ \\
\hline Burning area (ha) & 0.06 & 2 & 0.4 & 2 \\
\hline $\begin{array}{l}\text { Relative humidity RH (\%) } \\
\text { (min. and max.) }\end{array}$ & $20-23$ & $22-25$ & $24-25$ & $30-35$ \\
\hline Temperature $\left({ }^{\circ} \mathrm{C}\right)$ & $30-32$ & $22-24$ & $22-25$ & $14-16$ \\
\hline Wind velocity $\left(\mathrm{kmh}^{-1}\right)$ & 40 & 20 & $<5$ & $<5$ \\
\hline
\end{tabular}

tants. The paper is organized into three sections. Section 2 describes the experimental framework. Section 3 introduces the methodology and combines the results in term of exposure and risk assessment. Finally, Sect. 4 presents the conclusion.

\section{Experimental methods}

\subsection{Experimental plots and sampling and analysis}

Sampling was conducted on the island of Corsica, France in the western Mediterranean Sea at four different plots (Fig. 1). Table 1 presents the properties of the test plots and fuels. Selection of the plots was conducted by the National Forests 


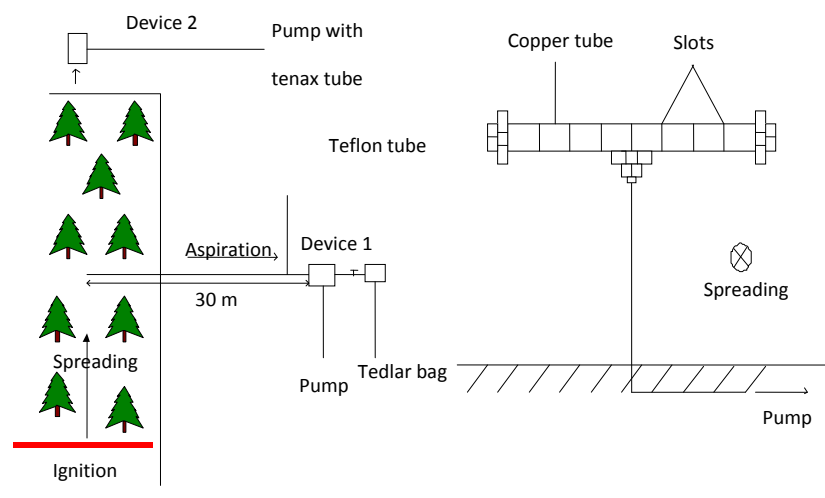

Fig. 2. Experimental devices for the smoke capture.

Office (ONS) of France and its operations staff for protection of forests against fire.

The first plot (1) was located in southern Corsica $\left(41^{\circ} 42^{\prime} \mathrm{N}, 09^{\circ} 20^{\prime} \mathrm{E}\right)$. During the summer, this area is frequently subject to wildfires because of windy conditions, high temperatures, and a high incidence of drought that increase the risk of wildfire occurrence. The experimental plot was rectangular, $30 \times 80 \mathrm{~m}^{2}$, with a slope of $<2^{\circ}$. A desertlike area was established around the plot to prevent the flame front from spreading beyond the area of the prescribed burn plot. The average height of the vegetation ranged from $80 \mathrm{~cm}$ to $2.5 \mathrm{~m}$. The vegetation consisted of several species, i.e., Quercus ilex L., Olea europaea L., Arbutus unedo L., Cistus monspeliensis L., Cytisus triflorus L., and Erica arborea $\mathrm{L}$. The plot was equipped with two devices for preconcentration of the smoke. For the other plots (2-4), only the second device was used.

The second plot (2) was located south of Corsica (Cuttoli, $\left.41^{\circ} 59^{\prime} \mathrm{N}, 08^{\circ} 54^{\prime} \mathrm{E}\right)$, near the city of Ajaccio. This plot was characterized by several plants, with A. unedo L., E. arborea L., and C. monspeliensis L. being the dominant species. Prescribed burning was conducted in collaboration with the ONF. The plot was $650 \mathrm{~m}$ a.s.l. with a slight slope of $<10 \%$.

The third plot (3) was located to the north of Corsica, (Corte, $42^{\circ} 18^{\prime} \mathrm{N}, 09^{\circ} 09^{\prime} \mathrm{E}, 450 \mathrm{~m}$, slope: $0 \%$, no wind). This plot was rectangular with an area of 0.4 ha. Burning was conducted by the Task Lights from the University of Corsica, in agreement with the prefect of Corsica, and firefighters. The vegetation consisted of $Q$. ilex $\mathrm{L}$.

The fourth plot (4) was located in southern Corsica in the Quenza region $\left(41^{\circ} 46^{\prime} \mathrm{N}, 09^{\circ} 08^{\prime} \mathrm{E}\right)$ at an altitude of $800 \mathrm{~m}$ and with a slope of 10-20\%. Prescribed burning was conducted by ONF. The plot was covered with Genista salzmanni $\mathrm{L}$.

Sampling was carried out by foresters who conducted the prescribed burning at the four plots. The distance between the sampling area and the fire front varied depending on the natural fire spread. Sampling began at the fire ignition point until the fire reached the sampling point (Fig. 2). The sam- pling area was located in the middle of the plot at a height ranging from $20 \mathrm{~cm}$ to $2 \mathrm{~m}$ (Fig. 2, right).

The first device consisted of a portable pump and a Tedlar bag. The pump was used to draw the smoke emitted from the burning vegetation through a heat-resistant Teflon tube. Sampling was carried out for $30 \mathrm{~min}$ at a flow rate of $500 \mathrm{~mL} \cdot \mathrm{min}^{-1}$. A cassette filter to trap larger particles was fitted at the entrance to the Tedlar bag. Water condensation was not a concern, because most of the studied compounds are insoluble or poorly soluble in water, and no water droplets or condensation were observed in the laboratory. The Tedlar bags were stored in opaque bags to minimize the effect of UV radiation during transportation to the laboratory. The smoke was then held in $25 \mathrm{~L}$ bags and each Tedlar bag was used only once. Only one experiment with this device was conducted at plot 1 .

The second device was composed of a portable pump connected to Tenax TA®tubes (Fig. 2). The Tenax TA tubes allow proportional adsorption of VOCs under high relative humidity. The volume of the sampled air did not exceed the breakthrough curves for the combination of adsorbed compounds. To ensure complete retention of VOCs on the adsorbents, trials with different concentrations of VOCs (Restek) were carried out by direct injection into the GC. The cartridge loading mode was through a gas path doped with a standard gas mixture (vaporization of standard solutions via a GC injector). There was no saturation of the samples, because all of the calibration curves were linear (partial quantification).

The tubes were placed in the breast pocket of a firefighter's jacket. Smoke was drawn from mixed samples (without distinguishing between flaming and smoldering phases) during the prescribed burn. The distance between the sampling area and the fire front ranged from 1 to $10 \mathrm{~m}$, depending on the position of the operations staff, four persons who controlled the fire using flaming torches. Each person was equipped with a portable sampling pump. Sampling was carried out for $15 \mathrm{~min}$ at a flow rate of $150 \mathrm{~mL} \cdot \mathrm{min}^{-1}$. The Tenax TA®sorbent tubes used were Multi-bed glass tubes $(11.5 \mathrm{~cm} \times 6 \mathrm{~mm}$ o.d. $\times 4 \mathrm{~mm}$ i.d.). The operations staff conducted sampling with the Tenax TA®tubes three different times during the prescribed burn to obtain 3 measurements per firefighter. Twelve samples were collected at each plot and analyzed ( 3 measurements $\times 4$ persons). In total, 48 samples (12 samples $\times 4$ sampling plots) were collected using device 2 .

The sorbent tubes and Tedlar bags were transferred to the lab and analyzed with an automatic thermal desorption-gas chromatography/mass spectrometer (ATD-GC/MS).

\subsection{ATD-GC/MS analysis}

The analyses were carried out one day after each experiment at the laboratory using an Automatic Thermal Desorber Perkin Elmer®ATD turbomatrix. For the thermal desorption 
of VOCs, helium (He) flow was set at $30 \mathrm{~mL} \mathrm{~min}^{-1}$ with a column head pressure at $25 \mathrm{psi}$. The sorbent tube was brought to $280^{\circ} \mathrm{C}$ in $10 \mathrm{~min}$ and a carrier gas flushed the sample toward a cold trap at $5^{\circ} \mathrm{C}$. In a second step, the cold trap $\left(22 \mathrm{~cm}, 0.53 \mathrm{~mm}\right.$ i.d.; Supelco $\left.{ }^{\circledR}\right)$ was programmed for an increase in temperature from $5^{\circ} \mathrm{C}$ to $280^{\circ} \mathrm{C}$ at $40^{\circ} \mathrm{C} \mathrm{s}^{-1}$ then held an isotherm at $280^{\circ} \mathrm{C}$ for $3 \mathrm{~min}$. The compounds were then desorbed to the chromatograph under helium as carrier via a heated transfer line maintained at $280^{\circ} \mathrm{C}$. The injector temperature was set to $280^{\circ} \mathrm{C}$. The energy ionization for mass detection was set to $70 \mathrm{eV}$ and electron ionization mass spectra were acquired over the mass range 35$350 \mathrm{Da}$. The chromatograph and the mass spectrometer are Perkin Elmer ${ }^{\circledR}$ Clarus $500^{\circledR}$ apparatus. The chromatograph was equipped with a non-polar column (Rtx-1, dimethylsiloxan), length: $60 \mathrm{~m}$ and internal diameter: $0.22 \mu \mathrm{m}$. This column was coupled to the mass detector. Detection was made using a quadrupole analyzer made up of an assembly of four parallel electrodes of cylindrical section. The oven temperature of the chromatograph was programmed from 50 to $260^{\circ} \mathrm{C}$ at $2^{\circ} \mathrm{C} \mathrm{min}^{-1}$ and then held isothermally at $260^{\circ} \mathrm{C}$ for $10 \mathrm{~min}$.

\subsection{Identification and quantification}

The methodology carried out for identification of individual components was based on:

- the comparison of their GC retention indices (RI) on non-polar and polar columns, with those of authentic compounds or literature data (König et al., 2001; NIST, 2005). RI on non-polar and polar columns was determined relative to the retention time of a series of $n$-alkanes with linear interpolation (Van Den Dool and Kratz, 1963);

- computer matching with commercial mass spectral libraries (Adams, 2001; König et al., 2001; NIST, 1999) and comparison of spectra with those of our laboratory-made library.

External calibration using standard compounds was conducted using commercial compounds $\left(\right.$ Restek $^{\circledR}$ : benzene, toluene, ethylbenzene, xylenes, styrene, propylbenzene, $\alpha$ methylstyrene, trimethylbenzene, diphenyl, phenol, o-cresol, 4-methoxyphenol, furfural and naphthalene). The method consists of injecting the compounds at known concentrations into the injection chamber of the $\mathrm{GC}$ at $240^{\circ} \mathrm{C}$. The $\mathrm{GC}$ is equipped with a short non-filled column heated to $240^{\circ} \mathrm{C}$ with a Tenax tube at the end of the column. Doping of the tube is through the gas path. Triplicate injections of standards were conducted at each of five points to obtain curves for the external calibration standards. The correlation coefficients $\left(R^{2}\right)$ for the linear regression of the curves for the external calibration standards were $0.987-0.999$, ensuring good correlation between the detector's response and the concentrations of the injected compounds.

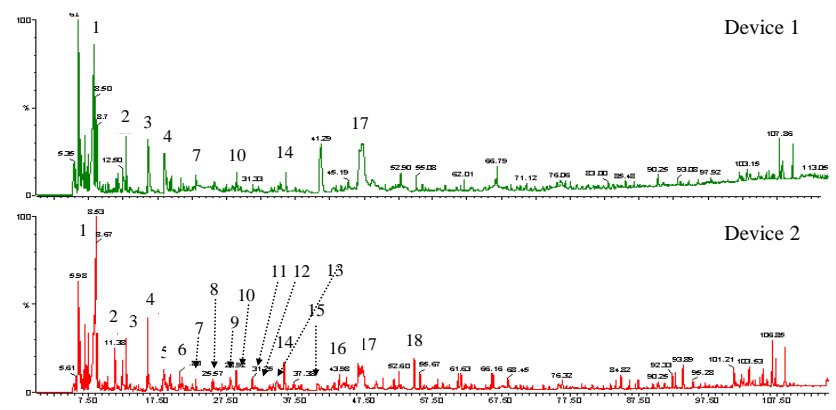

Fig. 3. Chromatogram profile of principal VOC in smoke from prescribed burnings (1: benzene, 2: toluene, 3: furfural, 4: ethylbenzene, 5: $(\mathrm{m}+\mathrm{p})$-xylene, 6: styrene, 7: o-xylene, 8: propylbenzene, 9: $\alpha$-methlstyrene, 10: phenol, 11 and 12: trimethylbenzene, 13: ocresol, 14: p-cresol, 15: m-cresol, 16: 4-methoxyphenol, 17: naphthalene, 18: biphenyl).

\subsection{Evaluation criteria for occupational exposure assessment}

Exposure risk assessment for humans (or firefighters) is defined by the European directive EN 481, in accordance with the International Organization for Standardization (ISO) and the ACGIH for many compounds inhaled by humans. The $\mathrm{LV}$ for a chemical compound represents the concentration in air that a person may breathe for a specified time without any risk to his or her health. Exposure to elevated levels of smoke can have short-term adverse health effects on humans. The exposure limit is given as a short-term exposure limit (STEL), which is designed to protect against the effects of peak exposures within a $15 \mathrm{~min}$ period, and a time weighted average (TWA), which is calculated over a period of $8 \mathrm{~h}$. Both limits are expressed in mass concentrations. These exposure limits are established by national agencies such as the American Conference of Governmental Industrial Hygienists (ACGIH), the Occupational Safety and Health Administration (OSHA) and the National Institute for Occupational Safety and Health (NIOSH) in the United States and the Institute for Research and Security (INRS) in France. Limit values may differ from one agency to the other (see Table 3).

\section{Results and discussion}

\subsection{Methodologies for pre-concentration of the VOCs in smoke}

Initially, it was necessary to establish a methodology for analyzing the VOCs present in the smoke. Both devices 1 and 2 were able to capture these compounds in the smoke. The main advantage of device 1 is that it allows a greater amount of sample to be captured and subsequently analyzed and the device is not selective; it pumps in the entire air-smoke mixture. Device 2 is selective and traps only the VOCs, 
increasing the concentrations of the compounds without altering their relative concentrations. Thus, it allows measurement of compounds in trace amounts that would not be measurable with device 1 . The adsorption of compounds is selective; it can adsorb certain classes of VOCs according to their nature (polarity, size, volatility, etc.). Device 2 allowed identification of a larger number of compounds (Fig. 3), i.e., 71 compounds using the pre-concentration tubes (device 2) versus 21 compounds using the Tedlar bags (device 1). This is because the Tedlar bags are nonselective samplers in which the VOCs are mixed with a large amount of air and ambient gases $\left(\mathrm{N}_{2}, \mathrm{O}_{2}, \mathrm{CO}_{2}, \mathrm{CO}\right.$, etc.) and thus, the VOCs may be present in trace amounts. Using device 1, the VOCs were diluted by the air and were frequently below the limit of detection (LOD) for the analytical instrument. Therefore, the number of VOCs identified was low. In contrast, the selective sampling device (device 2) allowed for adsorption of the desired molecules without air. When injected into the chromatograph, these molecules were sent to the column in higher concentrations. Upon receiving these results for plot 1 , device 2 was selected for use at the other three plots (2-4). Moreover, device 2 was simpler to use and more suited for determination of the actual quantities inhaled by the personnel, because the device was placed near their breathing zone.

\subsection{Analytical results and risk assessment}

ATD-GC-MS analysis of the samples from the four plots during the prescribed burns identified 79 compounds. The VOCs detected included benzene and phenol derivatives, organic acids, terpenic compounds, aliphatic hydrocarbons, aldehydes, and hazardous air pollutants. These results are consistent with the literature (Akagi et al., 2011; Statheropoulos and Karma, 2007; Evtyugina et al., 2013, 2014; Yokelson et al., 2008). It has been observed that, among the VOCs identified, benzene and related compounds are the most abundant group, followed by oxygenated compounds and aliphatic hydrocarbons (Evtyugina et al., 2014).

Among the detected compounds, 14 of the VOCs have existing toxicity data (STELs and TWAs) from INRS and ACGIH. These 14 VOCs were selected for quantitative analysis. Table 2 lists the VOCs identified in the smoke from the prescribed burns that are likely to cause adverse health effects. The United States Department of Agriculture (USDA) classifies the effects of smoke into three categories: shortterm effects including irritation, headache, and reduced capacity to work; intermediate effects such as temporary reduction in lung function, chronic bronchitis, etc.; and long-term effects comparable to those caused by inhalation of cigarette smoke. This suggests the possibility of developing cancer (for example, from benzene) or heart failure. Unfortunately, the long-term effects are not well studied, presenting challenges in assessing health risks due to exposure to toxic compounds in the smoke from prescribed burning.
The concentrations summarized in Table 3 are the maximum and minimum values obtained for a $15 \mathrm{~min}$ period from the 48 samples. Benzene, toluene, ethylbenzene, xylenes, and phenols were the primary toxic VOCs. The concentrations of the toxic VOCs in the present study were higher than those measured in previous studies (Barboni and Chiaramonti, 2010; Miranda et al., 2005; Reisen, 2006; Reisen and Brown, 2009; Statheropoulos and Karma, 2007). These higher values may be due to the sampling distance; during prescribed burns, the foresters are close to the flame $(<10 \mathrm{~m})$. This short distance influences the VOC concentration. For example, Statheropoulos and Karma (2007) reported that the benzene concentration was $0.696 \mathrm{mg} \mathrm{m}^{-3}$ at $70 \mathrm{~m}$ and $0.085 \mathrm{mg} \mathrm{m}^{-3}$ at $150 \mathrm{~m}$. Foresters are generally closer to the fire where the smoke is dense, and therefore knowing the VOC concentrations in this region is important. In addition, the specific conditions of the prescribed burn may have affected the concentrations. These burns involved fires set during non-drought periods when the vegetation was wet. In addition, the fire was controlled and less intense than a forest fire. Furthermore, during prescribed burning, the fires are of low intensity, ranging from 27 to $57 \mathrm{~kW} \mathrm{~m}^{-1}$ (Byram's intensity; Cannac et al., 2009). These conditions result in low combustion efficiency, and therefore the concentration of evolved gases is higher. Moreover, the foresters used flaming torches that also emit benzene and hydrocarbons, contributing to the measured concentrations due to the proximity between the sampling system (on the foresters' clothing) and the flaming torches. Moreover, the foresters constantly fed the fire with their flaming torches (Reisen and Brown, 2009). Some compounds present in diesel/gasoline such as alkane hydrocarbons (Barboni et al., 2010b) accumulate in the emitted smoke and are inhaled by foresters. Reinhardt and Ottmar (2004) reported that evolved benzene originates in part from the engines and torches burning petroleum-based fuel. Thus, differences in fuel characteristics such as fuel type, fuel load, and fuel moisture can influence the combustion efficiency and the resulting concentrations of compounds in the smoke (Santoni et al., 2011).

Table 3 shows the concentrations of the 14 toxic VOCs in the smoke arising from prescribed burning compared to the occupational exposure limits. Benzene, phenol and furfural exceeded the STEL values for $15 \mathrm{~min}$ sampling duration. The benzene concentration was $27-54 \mathrm{mg} \mathrm{m}^{-3}$, while the recommendation states that it should not exceed $0.32-16 \mathrm{mg} \mathrm{m}^{-3}$ (STEL). Exposure to $160 \mathrm{mg} \mathrm{m}^{-3}$ benzene for $60 \mathrm{~min}$ can produce nausea, whereas exposure to $16-50 \mathrm{mg} \mathrm{m}^{-3}$ benzene for $5 \mathrm{~h}$ results in headache, lassitude, and weakness (NIOSH, 2006). The phenol concentration was $12-29 \mathrm{mg} \mathrm{m}^{-3}$, generally exceeding the STEL level from INRS $\left(15.6 \mathrm{mg} \mathrm{m}^{-3}\right)$, but not the limit value from NIOSH $\left(60 \mathrm{mg} \mathrm{m}^{-3}\right)$. The concentration of furfural was $3.2-19 \mathrm{mg} \mathrm{m}^{-3}$, partially exceeding the STEL values given by INRS $\left(8 \mathrm{mg} \mathrm{m}^{-3}\right)$. Widespread irritation in the eye and respiratory tract has been noted in workers exposed to concentrations of $10-32 \mathrm{mg} \mathrm{m}^{-3}$. 
Table 2. Toxicity of 14 VOCs emitted by vegetation during the prescribed burnings (INERS and ACGIH).

\begin{tabular}{|c|c|}
\hline Compound & Toxicity \\
\hline Ethylbenzene & Irritation eyes, skin, mucous membrane; headache; dermatitis; narcosis, coma \\
\hline Styrene & $\begin{array}{l}\text { Irritation eyes, nose, respiratory system; headache, lassitude (weakness, exhaustion), dizziness, confusion, } \\
\text { malaise (vague feeling of discomfort), drowsiness, unsteady gait; narcosis; defatting dermatitis; possible liver } \\
\text { injury; reproductive effects }\end{array}$ \\
\hline Biphenyl & Irritation eyes, throat; headache, nausea, lassitude (weakness, exhaustion), numb limbs; liver damage \\
\hline Phenol & $\begin{array}{l}\text { Irritation eyes, nose, throat; anorexia, weight loss; lassitude (weakness, exhaustion), muscle ache, pain; dark } \\
\text { urine; cyanosis; liver, kidney damage; skin burns; dermatitis; ochronosis; tremor, convulsions, twitching }\end{array}$ \\
\hline Cresols & $\begin{array}{l}\text { Irritation eyes, skin, mucous membrane; central nervous system effects: confusion, depression, resp failure; } \\
\text { dyspnea (breathing difficulty), irreg rapid resp, weak pulse; eye, skin burns; dermatitis; lung, liver, kidney, } \\
\text { pancreas damage }\end{array}$ \\
\hline 4-methoxyphenol & Irritation eyes, skin, nose, throat, upper respiratory system; eye, skin burns; central nervous system depression \\
\hline
\end{tabular}

Headache, throat irritation, and red and watery eyes have been observed at concentrations of $3.8-28 \mathrm{mg} \mathrm{m}^{-3}$.

To evaluate exposure to a mixture of smoke pollutants, a mathematical formula can be used to sum the individual contributions to the LV. The respiratory irritant exposure index $E_{m}$ was calculated as below, where $C_{i}$ is the concentration of component $i\left(\mathrm{mg} \cdot \mathrm{m}^{-3}\right.$ in air) (Reisen and Brown, 2009; Slaughter et al., 2004):

$E_{\mathrm{m}}=\sum_{i=1}^{n} \frac{C_{i}}{\text { STEL }_{i}} \leq 1$.

STEL values are not available for all of the VOCs included in Table 3. Benzene, toluene, ethylbenzene, xylenes, and styrene (BTEXS) cause irritation of the respiratory tract and mucous membranes. The $E_{m}$ for the BTEXS pollutants based on the STEL values (using the minimum values given by INRS, ACGIH, NIOSH, or OSHA) for the maximum concentration of the BTEXS pollutants (Table 3) was 169, much greater than 1 . These five compounds were present at high concentrations with a risk for substantial irritation to the forester. When this coefficient was calculated excluding benzene, which individually exceeded its STEL, $E_{m}$ was 0.28 . TEXSs have relatively low toxicity, as their STEL values are high.

For phenol and phenol derivatives, the Em coefficient was calculated by extrapolating the TWAs provided by ACGIH. The exposure index $E_{m}$ for phenol and phenol derivatives was 3 , also greater than 1 . Therefore, these compounds are also strong potential irritants and warrant consideration in reducing health risks for foresters. The $E_{m}$ for the phenol derivatives (without phenol) was 1.5. Thus, the amount of these compounds, all with similar toxic potential, influences the quality of air inhaled by the foresters during prescribed burning, although during prescribed burning, firefighters are not daily exposed to $8 \mathrm{~h}$ of smoke and neither do they work throughout the year under such conditions. In 
Table 3. Concentrations of major toxic VOCs emitted by vegetation during the prescribed burnings.

\begin{tabular}{lccc}
\hline Compounds & $\begin{array}{c}\text { Concentration } \\
(\text { min-max }) \\
\left(\mathrm{mg} \mathrm{m}^{-3}\right)\end{array}$ & STEL & TWA \\
\hline Benzene & $27-54$ & $16^{\mathrm{d}}, 8.1^{\mathrm{b}}, 0.32^{\mathrm{c}}$ & $30^{\mathrm{b}}, 3.2^{\mathrm{c}, \mathrm{d}}$ \\
Toluene & $28-42$ & $560^{\mathrm{c}}, \mathrm{d}$ & $188^{\mathrm{b}}, 375^{\mathrm{c}}, \mathrm{d}$ \\
Ethylbenzene & $22-67$ & $543^{\mathrm{b}-\mathrm{d}}$ & $434^{\mathrm{b}-\mathrm{d}}$ \\
(o+m+p)-xylene & $19-37$ & $655^{\mathrm{b}-\mathrm{d}}$ & $435^{\mathrm{b}-\mathrm{d}}$ \\
Styrene & $1.0-7.6$ & $425^{\mathrm{b}-\mathrm{d}}$ & $215^{\mathrm{b}-\mathrm{d}}$ \\
Propylbenzene & tr-4.7 & - & $245^{\mathrm{b}}$ \\
$\alpha$-methylstyrene & $<3.8$ & $483^{\mathrm{b}-\mathrm{d}}$ & $242^{\mathrm{b}-\mathrm{d}}$ \\
Trimethylbenzene & $<3.8$ & - & $123^{\mathrm{b}}$ \\
Diphenyl & $<0.8$ & - & $1.5^{\mathrm{b}-\mathrm{d}}$ \\
Phenol & $12-29$ & $15.6^{\mathrm{a}} 60^{\mathrm{c}}$ & $7.8^{\mathrm{a}}, 19^{\mathrm{b}-\mathrm{d}}$ \\
Cresols (o+m+p) & $3-14$ & - & $22^{\mathrm{b}-\mathrm{d}}, 12^{\mathrm{c}}$ \\
4-methoxyphenol & $0.2-4.4$ & - & $5^{\mathrm{c}}$ \\
\hline Furfural & $3.2-19$ & $8^{\mathrm{a}}$ & $7.9^{\mathrm{b}}, 13$ \\
Naphtalene & $1.2-4.2$ & $75^{\mathrm{b}-\mathrm{d}}$ & $50^{\mathrm{b}-\mathrm{d}}$ \\
\hline
\end{tabular}

a INRS; ${ }^{\mathrm{b}}$ ACGIH; ${ }^{\mathrm{c}} \mathrm{NIOSH} ;{ }^{\mathrm{d}}$ OSHA

Corsica, firefighters work on 80 ha of land per year. It is difficult to establish a correlation between the exposure to smoke during a prescribed burn and the LVs established by authorities for protection of workers. Nevertheless, it is apparent that the higher concentrations of benzene, phenol, and furfural exceeded the STEL.

\section{Conclusions}

In the present study, chemical analysis of the smoke released from prescribed burning in Corsica was conducted using ATD-GC/MS. Pre-concentration of the VOCs was found to be the most appropriate method allowing low detection limit analysis of the VOCs present in the smoke samples. The level of toxicity due to VOCs present in the smoke was also determined based on known toxicity data. However, STEL and TWA values are missing for many compounds present in the smoke samples. The risk assessment showed that concentrations of benzene, phenol, and furfural exceeded the STEL. The potential toxicities of benzene and phenol derivatives were greater than 1 , implying that the atmosphere was toxic for the foresters. Thus, two recommendations are provided. As a precaution, foresters should not work for $>8 \mathrm{~h}$ without protection or should wear a protective respirator. In addition, using a method of fire ignition other than flaming torches is suggested, because this method may increase potential exposure to high concentrations of toxic compounds.

Acknowledgements. The authors thank the ONF and the regional foresters for carrying out prescribed burns at the study plots.

Edited by: C. Mari

Reviewed by: two anonymous referees

\section{References}

Adams, R. P.: Identification of Essential Oils by Capillary Gas Chromatography/Mass Spectroscopy, Allured, Carol Stream, IL, 2001.

Alves, C. A., Vicente, A., Monteiro, C., Gonçalves, C., Evtyugina, M., and Pio, C.,: Emission of trace gases and organic components in smoke particles from a wildfire in a mixed-evergreen forest in Portugal, Sci. Tot. Environ., 409, 1466-1475, 2011.

American Conference of Governmental Industrial Hygienists: available at: http://www.acgih.org/home.htm (last access: 2012), 2001.

Andreae, M. O. and Merlet, P.: Emission of trace gases and aerosols from biomass burning, Global Biogeochem. Cy., 15, 955-966, 2001.

Barboni, T., Chiaramonti, N., Leoni, E., Desjobert, J. M., and Santoni, P. A.: Analysis of smoke during prescribed fire, 1st International Symposium on Environment Identities and Mediterranean Area, ISEIM, art. no. 4150430, IEEE, Corte, France, doi:10.1109/ISEIMA.2006.345041, 18-23, 2006.

Barboni, T. and Chiaramonti, N.: BTEXs emissions according to the distance from the flame front and the combustion stages during the prescribed burning, Combust. Sci. Technol., 182, 1193-1200, 2010.

Barboni, T., Pelizzaro, G., Arca, B., Chiaramonti, N., and Duce, P.: Analysis and origins of smoke from ligno-cellulosic fuels, J. Anal. Appl. Pyrol., 89, 60-65, 2010a.

Barboni, T., Cannac, M., Pasqualini, V., Simeoni, A., Leoni, E., and Chiaramonti, N.: Volatile and semi-volatile organic compounds in smoke exposure of firefighters during prescribed burning in the Mediterranean region, Int. J. Wildland Fire, 19, 606-612, 2010b.

Barboni, T., Cannac, M., Leoni, E., and Chiaramonti, N.: Emission of biogenic volatile organic compounds involved in eruptive fire: implications for the safety of firefighters, Int. J. Wildland Fire, 20, 152-161, 2011.

Betchley, C., Koenig, J. Q., van Bell, G., Checkoway, H., and Reinhardt, T.: Pulmonary function and respiratory symptoms in forest firefighters, Am. J. Ind. Med., 31, 503-509, 1997.

Cannac, M., Barboni, T., Ferrat, L., Bighelli, A., Castola, V., Costa, J., Trecul, D., Morandini, F., and Pasqualini, V.: Oleoresin Flow and Chemical Composition of Corsican Pine (Pinus laricio) in Response to Prescribed Burnings, Forest Ecol. Manag., 257, 1247-1254, 2009.

Ciccioli, P., Brancaleoni, E., Frattoni, M., Cecinato, A., and Pinciarelli, L.: Determination of volatile organic compounds (VOC) emitted from biomass burning of Mediteranean vegetation species by GC-MS, Anal. Lett., 34, 937-955, 2001.

De Vos, A. J. B. M., Reisen, F., Cook, A., Devine, B., and Weinstein, P.: Respiratory irritants in 246 Australian bushfire smoke: air toxics sampling in a smoke chamber and during prescribed burns, Arch. Environ. Con. Tox., 56, 380-388, 2009.

Dokas, I., Statheropoulos, M., and Karma, S.: Integration of field chemical data in initial risk assessment of forest fire smoke, Sci. Total Environ., 376, 72-85, 2007.

Dost, F. N.: Acute toxicology of components of vegetation smoke, Rev. Environ. Contam. T., 119, 1-46, 1991.

Evtyugina, M., Calvo, A. I., Nunes, T., Alves, C., Fernandes, A. P., Tarelho, L., Vicente, A., and Pio, C.: VOC emissions of smouldering combustion from Mediterranean wildfires in central Portugal, Atmos. Environ., 64, 339-348, 2013. 
Evtyugina, M., Alves, C., Calvo, A., Nunes, T., Tarelho, L., Duarte, M., Prozil, S., Evtugin, D., and Pio, C.: VOC emissions from residential combustion of Southern and mid-European woods, Atmos. Environ., 83, 90-98, 2014.

Friedli, H. R., Atlas, E., Stroud, V. R., Giovanni, L., Campos, T., and Radke, L. F.: Volatile organic trace gases emitted from North American wildfires, Global Biogeochem. Cy., 15, 435452, 2001

Gouw, J. A., Warneke, C., Stohl, A., Wollny, A. G., Brock, C. A., Cooper, O. R., Holloway, J. S., Trainer, M., Fehsenfeld, F. C., Atlas, E. L., Stroud, V., and Lueb, A.: Volatile organic compounds composition of merged and aged forest fire plumes from Alaska and western Canada, J. Geophys. Res. Atmos., 111, D10303, 2006.

INRS: Values for the health, available at: (last access: 2012), 2010. Immediately Dangerous to Life or Health (IDLH): Documentation, National Institute for Occupational Safety and Health (NIOSH), available at: http://www.cdc.gov/NIOSH/idlh/71432.html (last access: November 2006), 1994.

König, W. A., Hochmuth, D. H., and Joulain, D.: Terpenoids and related constituents of essential oils, library of massfinder 2.1. Hamburg: University of Hamburg, Institute of Organic Chemistry, 2001.

Liu, D., Tager, I. B., Balmes, J. R., and Harrison, R. J.: The effect of smoke inhalation on lung function and airway responsiveness in wildland fire fighters, Am. Rev. Respir. Dis., 146, 1469-1473, 1992.

Malilay, J.: A review of factors affecting the human health impacts of air pollutants from forest fires, in: Health Guidelines for Vegetation Fire Events: Background Papers, World Health Organization, Geneva, 255-270, 1999.

Materna, B. L., Jones, J. R., Sutton, P. M., Rothman, N., and Harrison, R. J., Occupational exposures in California wildland firefighting, Am. Ind. Hyg. Assoc. J., 53, 69-76, 1992.

Miranda, A. I., Borrego, C., and Viegas, D. X.: Forest fire effects on the air quality, in: Proceedings of the Second International Conference on Air Pollution, edited by: Baldasano, J., Brebbia, C., Power, H., and Zannetti, P., Computer SimulationSpain, Barcelona, 191-199, 1994.

Miranda, A. I.: An integrated numerical system to estimate air quality effects of forest fires, Int. J. Wildland Fire, 13, 217-226, 2004.

Miranda, A. I., Ferreira, J., Valente, J., Santos, P., Amorim, J. H., and Borrego, C., Smoke measurements during Gestosa-2002 experimental field fires, Int. J. Wildland Fire, 14, 107-116, 2005.

Miranda, A. I., Martins, V., Cascão, P., Amorim, J. H., Valente, J., Tavares, R., Borrego, C., Tchepel, O., Ferreira, A. J., Cordeiro, C. R., Viegas, D. X., Ribeiro, L. M., and Pita, L. P., Monitoring of firefighters exposure to smoke during fire experiments in Portugal, Environ. Int., 36, 736-745, 2010.

Muraleedharan, T. R., Radojevic, M., Waugh, A., and Caruana, A., Chemical characterisation of the haze in Brunei Darussalam during the 1998 episode, Atmos. Environ., 34, 2725-2731, 2000.

Mustajbegovic, J., Zuskin, E., Schachter, E. N., Kern, J., VrcicKeglevic M., and Heimer, M. S.: Respiratory function in active firefighters, Am. J. Ind. Med., 40, 55-62, 2001.

National Institute of Standards and Technology (NIST): NIST WebBook, available at: http://webbook.nist.gov/chemistry (last access: 2012), 2005.
Occupational Safety and Health Administration, OSHA Permissible Exposure Limit (PEL) - General Industry, available at: www.osha.gov/ (last access: 2012), 1998.

Reinhardt, T. E., Ottmar, R. D., and Castilla, C.: Smoke impacts from agricultural burning in a rural Brazilian Town, J. Air Waste Manage., 51, 443-505, 2001.

Reinhardt, T. E. and Ottmar, R. D.: Baseline measurements of smoke exposure among wildland firefighters, J. Occup. Environ. Hyg., 1, 593-606, 2004.

Reinhardt, T. E., Ottmar, R. D., and Hanneman, A.: Smoke exposure among firefighters at prescribed burns in the Pacific Northwest, United States Department of Agriculture Forest Service, Pacific Northwest Research Station, 2000.

Reisen, F.: Air Toxics in Bushfire Smoke: Firefighter's Exposure during Prescribed Burns, V International Conference on Forest Fire Research, 2006.

Reisen, F. and Brown, S. K.: Australian firefighters' exposure to air toxics during bushfire burns of autumn 2005 and 2006, Environ. Int., 35, 342-352, 2009.

Rothman, N., Ford, D. P., Baser, M. E., Hansen, J. A., Toole, T. O., Tockman, M. S., and Strickland, P. T.: Pulmonary function and respiratory symptoms in wildland firefighters, J. Occup. Environ. Med., 33, 1163-1169, 1991.

Santoni, P. A., Morandini, F., and Barboni, T.: Determination of fireline intensity by oxygen consumption calorimetry, J. Therm. Anal. Calorim., 104, 1005-1015, 2011.

Shirai, T., Blake, D. R., Meinardi, S., Rowland, F. S., Russell-Smith, J., Edwards, A., Kondo, Y., Koike, M., Kita, K., Machida, T., Takegawa, N., Nishi, N., Kawakami, S., and Ogawa T.: Emission estimates of selected volatile organic compounds from tropical savanna burning in northern Australia, J. Geophys. Res., 108, 8406, 2003.

Shauer, J. J., Kleeman, M. J., Cass, G., and Simoneit, B. T., measurement of emissions from air pollution sources. 3. C1-C29 organic compounds from fireplace combustion of wood, Environ. Sci. Technol., 35, 716-28, 2001.

Sinha, P., Hobbs, P. V., Yokelson, R. J., Bertschi, I. T., Blake, D. R., Simpson, I. J., Gao, S., Kirchstetter, T. W., and Novakov T.: Emissions of trace gases and particles from savanna fires in southern Africa, J. Geophys. Res., 108, D8487, 2003.

Sinha, P., Hobbs, P. V., Yokelson, R. J., Blake, D. R., Simpson, I. J., Gao, S., and Kirchstetter, T. W.: Emissions from miombo woodland and dambo grassland savanna fires, J. Geophys. Res., 109, D11305, 2004.

Slaughter, J. C., Koenig, J. Q., and Reinhardt, T. E.: Association between lung function and exposure to smoke among firefighters at prescribed burns, J. Occup. Environ. Hyg., 1, 45-49, 2004.

Statheropoulos, M. and Karma, S.: Complexity and origin of the smoke components as measured near the flame-front of a real forest fire incident: a case study, J. Anal. Appl. Pyrol., 78, 430 437, 2007.

Urbanski, J., Yokelson, R. J., Hao, W. M., and Baker, S.: Chemical Composition of Wildland Fire Emissions in: Bytnerowicz, A., Arbaugh, M., Riebau, A., Anderssen, C. (Eds.), Wildland Fires and Air Pollution, Developments in Environmental Science, V. 8, Elsevier, Amsterdam, p. 79-107, 2008.

US National Institute of Standards and Technology: PC Version 1.7 of the NIST/EPA/NIH Mass Spectra Library, Norwalk, CT, 1999. 
Van Den Dool, H. and Kratz, P. D.: A generalization of the retention index system including linear temperature programmed gasliquid partition chromatography, J. Chromatogr., 11, 463-471, 1963.

Vicente, A., Alves, C., Monteiro, C., Nunes, T., Mirante, F., Cerqueira, M., Calvo, A., and Pio, C.: Organic speciation of aerosols from wildfires in central Portugal during summer 2009, Atmos. Environ., 57, 186-196, 2012.

Vicente, A., Alves, C., Calvo, A., Fernandes, A. P., Nunes, T., Monteiro, C., Almeida, S. A., and Pio, C.: Emission factors and detailed chemical composition of smoke particles from the 2010 wildfire season, Atmos. Environ., 71, 295-303, 2013.

Ward, D., Rothermel, R., and Bushey, C.: Particulate Matter and Trace Gas Emissions from the Canyon Creek Fire Of 1988, in: Society of American Foresters Proceedings of the 12th Fire and Forest Meteorology, Georgia, United States of America, 62-76, 1973.
Ward, D. E.: Smoke from wildland fires, in: Health Guidelines for Vegetation Fire Events - Background Papers, edited by: Goh, K.T., Schwela, D., Goldammer, J. G., and Simpson, O., 6-9 October 1998, WHO/UNEP/WMO, Lima, Peru, 70-85, 1999.

Yokelson, R. J., Karl, T., Artaxo, P., Blake, D. R., Christian, T. J., Griffith, D. W. T., Guenther, A., and Hao, W. M.: The Tropical Forest and Fire Emissions Experiment: overview and airborne fire emission factor measurements, Atmos. Chem. Phys., 7, 5175-5196, doi:10.5194/acp-7-5175-2007, 2007.

Yokelson, R. J., Christian, T. J., Karl, T. G., and Guenther, A.: The tropical forest and fire emissions experiment: laboratory fire measurements and synthesis of campaign data, Atmos. Chem. Phys., 8, 3509-3527, doi:10.5194/acp-8-3509-2008, 2008. 